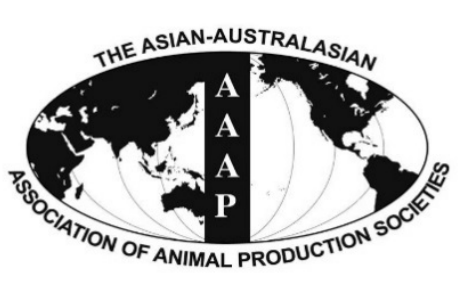

Open Access

Asian Australas. J. Anim. Sci.

Vol. 29, No. 11 : 1625-1631 November 2016

http://dx.doi.org/10.5713/ajas.15.0825

www.ajas.info

pISSN 1011-2367 elSSN 1976-5517

\title{
Casein Supplementation Does Not Affect the Estimates of True Total Tract Digestibility of Phosphorus in Soybean Meal for Growing Pigs Determined by the Regression Method
}

\author{
J. B. Liu and O. Adeola* \\ Department of Animal Sciences, Purdue University, West Lafayette, IN 47907-2054, USA
}

\begin{abstract}
Forty-eight barrows with an average initial body weight of $25.5 \pm 0.3 \mathrm{~kg}$ were assigned to 6 dietary treatments arranged in a $3 \times 2$ factorial of 3 graded levels of $P$ at $1.42,2.07$, or $2.72 \mathrm{~g} / \mathrm{kg}$, and 2 levels of casein at 0 or $50 \mathrm{~g} / \mathrm{kg}$ to compare the estimates of true total tract digestibility (TTTD) of P in soybean meal (SBM) for pigs fed diets with or without casein supplementation. The SBM is the only source of P in diets without casein, and in the diet with added casein, 1.0 to $2.4 \mathrm{~g} / \mathrm{kg}$ of total dietary P was supplied by SBM as dietary level of SBM increased. The experiment consisted of a 5-d adjustment period and a 5-d total collection period with ferric oxide as a maker to indicate the initiation and termination of fecal collection. There were interactive effects of casein supplementation and total dietary P level on the apparent total tract digestibility (ATTD) and retention of P ( $<<0.05)$. Dietary P intake, fecal P output, digested $\mathrm{P}$ and retained $\mathrm{P}$ were increased linearly with graded increasing levels of SBM in diets regardless of casein addition $(\mathrm{p}<0.01)$. Compared with diets without casein, there was a reduction in fecal $\mathrm{P}$ in the casein-supplemented diets, which led to increases in digested $\mathrm{P}$, retained $P$, ATTD, and retention of $\mathrm{P}(\mathrm{p}<0.01)$. Digested N, ATTD of N, retained N, and $\mathrm{N}$ retention were affected by the interaction of casein supplementation and dietary $\mathrm{P}$ level $(\mathrm{p}<0.05)$. Fecal $\mathrm{N}$ output, urinary $\mathrm{N}$ output, digested $\mathrm{N}$, and retained $\mathrm{N}$ increased linearly with graded increasing levels of SBM for each type of diet $(\mathrm{p}<0.01)$. The estimates of TTTD of P in SBM, derived from the regression of daily digested $\mathrm{P}$ against daily $\mathrm{P}$ intake, for pigs fed diets without casein and with casein were calculated to be $37.3 \%$ and $38.6 \%$, respectively. Regressing daily digested $\mathrm{N}$ against daily $\mathrm{N}$ intake, the TTTD of $\mathrm{N}$ in SBM were determined at $94.3 \%$ and $94.4 \%$ for diets without casein and with added casein, respectively. There was no difference in determined values of TTTD of P or N in SBM for pigs fed diets with or without casein $(\mathrm{p}>0.05)$. In summary, our results demonstrate that the estimates of TTTD of P in SBM for pigs were not affected by constant casein inclusion in the basal diets. (Key Words: Casein, Phosphorus, Pig, Soybean Meal, True Total Tract Digestibility)
\end{abstract}

\section{INTRODUCTION}

The majority of $\mathrm{P}$ in grains is bound to phytate, which leads to a poor utilization of $\mathrm{P}$ by swine (Cromwell, 1980; Raboy, 1997; Weremko et al., 1997). Apparent P digestibility was used to measure the $\mathrm{P}$ utilization in previous studies (Jongbloed et al., 1992; Fan and Sauer, 2002). However, true total tract digestibility (TTTD) of $P$ is preferred to determine the $\mathrm{P}$ utilization using the regression method due to the account for the confounding effect of

\footnotetext{
* Corresponding Author: O. Adeola. Tel: +1-765-494-4848, Fax: +1-765-494-9346, E-mail: ladeola@purdue.edu Submitted Oct. 7, 2015; Revised Dec. 14, 2015; Accepted Jan. 18, 2016
}

endogenous P loss (EPL) in recent years (Fan et al., 2001; Ajakaiye et al., 2003; Dilger and Adeola, 2006; Akinmusire and Adeola, 2009).

Semi-purified diets, used for the determination of TTTD of $\mathrm{P}$ associated with feedstuffs, are different from practical diets for swine in dietary P sources and amino acid profiles. In experimental situations, the semi-purified diets were used to determine TTTD of $\mathrm{P}$ in feedstuffs for swine and poultry, which in general derive all the $P$ from the test feedstuff (Fan et al., 2001; Dilger and Adeola, 2006; Akinmusire and Adeola, 2009). However, ingredients containing high $\mathrm{P}$ digestibility are included in practical diets (Stein et al., 2008). Furthermore, the protein quality in practical diets may be higher than that in semi-purified diets and dietary 
protein quality could be improved by the supplementation of casein (contains highly digestible amino acids). It has been reported that the estimates of metabolizable energy content of corn distillers dried grains with soluble by the regression method are not consistent between semi-purified and practical diets (Adeola and Ileleji, 2009). It is noteworthy that the estimates of TTTD of P in feedstuffs obtained from experimental semi-purified diets are used for diet formulation based on $\mathrm{P}$ evaluation studies for digestibility in feed ingredients and the assumption of additivity. However, there is no report on the effects of additional highly digestible $\mathrm{P}$ source inclusion in the basal diets and dietary protein quality of semi-purified diets on the determination of TTTD of P in soybean meal (SBM) for pigs. Therefore, the objective of the current study was to use the regression method to compare the determined values of TTTD of P and EPL associated with SBM in pigs fed diets without or with casein.

\section{MATERIALS AND METHODS}

All animal protocols were approved by the Purdue University Animal Care and Use Committee.

\section{Diets and experimental design}

The six dietary treatments (Table 1) consisted of 3 graded P concentrations $(1.42,2.07$, or $2.72 \mathrm{~g} / \mathrm{kg})$, and 2 diet type (without or with casein supplementation) arranged in a $3 \times 2$ factorial. The SBM levels were 200,310 , or 420 $\mathrm{g} / \mathrm{kg}$ and 145,255 , or $365 \mathrm{~g} / \mathrm{kg}$ in the diets without and with casein, respectively. Diets were semipurified and based on SBM, cornstarch, dextrose, and sucrose. The concentrations of SBM in diets were increased at the expense of cornstarch. The only $\mathrm{P}$ source in diets without casein was SBM, while P in casein-supplemented diets were derived from SBM and casein. All diets were formulated to have a constant Ca:total $\mathrm{P}$ ratio at 1.2:1 by adjusting limestone.

\section{Animals, feeding and sample collection}

Forty-eight barrows, with an average initial body weight (BW) of $25.5 \pm 0.3 \mathrm{~kg}$, were assigned to 6 dietary treatments according to a randomized complete block design with 8 replicates per diet. All the pigs were placed in metabolism crates $(0.83$ by $0.71 \mathrm{~m})$ and randomly allocated to the 6 dietary treatments such that the average initial BW of pigs was similar among treatment groups. The metabolism crates were located in an environmentally controlled room with a

Table 1. Ingredient composition of the experimental diets (as-fed basis)

\begin{tabular}{|c|c|c|c|c|c|c|}
\hline \multirow[t]{2}{*}{ Item $(\mathrm{g} / \mathrm{kg})$} & \multicolumn{3}{|c|}{$\begin{array}{l}\text { Without casein }(0 \mathrm{~g} / \mathrm{kg}) \text {, } \\
\text { dietary total } \mathrm{P} \text { level }(\mathrm{g} / \mathrm{kg})\end{array}$} & \multicolumn{3}{|c|}{$\begin{array}{c}\text { With casein }(50 \mathrm{~g} / \mathrm{kg}) \\
\text { dietary total P level }(\mathrm{g} / \mathrm{kg})\end{array}$} \\
\hline & 1.42 & 2.07 & 2.72 & 1.42 & 2.07 & 2.72 \\
\hline \multicolumn{7}{|l|}{ Ingredients } \\
\hline Soybean meal (crude protein $48 \%$ ) & 200.0 & 310.0 & 420.0 & 145.0 & 255.0 & 365.0 \\
\hline Cornstarch & 520.9 & 409.6 & 298.3 & 525.8 & 414.5 & 303.2 \\
\hline Soybean oil & 20.0 & 20.0 & 20.0 & 20.0 & 20.0 & 20.0 \\
\hline Salt & 3.3 & 3.3 & 3.3 & 3.3 & 3.3 & 3.3 \\
\hline Sucrose & 150.0 & 150.0 & 150.0 & 150.0 & 150.0 & 150.0 \\
\hline Dextrose & 100.0 & 100.0 & 100.0 & 100.0 & 100.0 & 100.0 \\
\hline Limestone & 2.8 & 4.1 & 5.4 & 2.9 & 4.2 & 5.5 \\
\hline Casein & 0.0 & 0.0 & 0.0 & 50.0 & 50.0 & 50.0 \\
\hline Vitamin premix $^{1}$ & 1.5 & 1.5 & 1.5 & 1.5 & 1.5 & 1.5 \\
\hline Mineral premix ${ }^{2}$ & 1.0 & 1.0 & 1.0 & 1.0 & 1.0 & 1.0 \\
\hline Selenium premix ${ }^{3}$ & 0.5 & 0.5 & 0.5 & 0.5 & 0.5 & 0.5 \\
\hline Total & $1,000.0$ & $1,000.0$ & $1,000.0$ & $1,000.0$ & $1,000.0$ & $1,000.0$ \\
\hline \multicolumn{7}{|l|}{ Calculated nutrient composition ${ }^{4}$} \\
\hline $\mathrm{N}$ & 15.77 & 24.25 & 32.74 & 18.60 & 27.08 & 35.57 \\
\hline $\mathrm{Ca}$ & 1.70 & 2.50 & 3.29 & 1.69 & 2.48 & 3.28 \\
\hline Total P & 1.42 & 2.07 & 2.72 & 1.42 & 2.07 & 2.72 \\
\hline \multicolumn{7}{|l|}{ Analyzed nutrient composition } \\
\hline $\mathrm{N}$ & 16.18 & 23.30 & 31.34 & 18.33 & 27.73 & 35.20 \\
\hline $\mathrm{Ca}$ & 1.58 & 2.47 & 3.11 & 1.71 & 2.42 & 3.19 \\
\hline Total P & 1.28 & 1.95 & 2.61 & 1.32 & 1.91 & 2.58 \\
\hline
\end{tabular}

${ }^{1}$ Provided per kilogram of diet: 3,630 IU of vitamin A; 363 IU of vitamin D; 36.4 IU of vitamin E; $1.3 \mathrm{mg}$ of vitamin K (menadione sodium bisulfite); $23.1 \mu \mathrm{g}$ of vitamin $\mathrm{B}_{12} ; 5.28 \mathrm{mg}$ of riboflavin; $13.1 \mathrm{mg}$ of D-pantothenic acid; $19.8 \mathrm{mg}$ of niacin.

${ }^{2}$ Provided per kilogram of diet: $121 \mathrm{mg}$ of $\mathrm{Fe}$ (as iron carbonate); $15 \mathrm{mg}$ of $\mathrm{Mn}$ (as manganese oxide); $11.3 \mathrm{mg}$ of Cu (as copper chloride); $0.46 \mathrm{mg}$ of I (as ethylenediamine dihydroiodide); and $121 \mathrm{mg}$ of $\mathrm{Zn}$ (as zinc oxide).

${ }^{3}$ Selenium premix provided $300 \mu \mathrm{g}$ of Se per kilogram of diet.

${ }^{4}$ The nutrient composition of diets was calculated according to NRC (2012). 
temperature of $21^{\circ} \mathrm{C} \pm 2^{\circ} \mathrm{C}$. Feed allowance was calculated as approximately $4 \%$ of initial $\mathrm{BW}$ of each pig during the experimental period. The barrows were fed one-half of the daily feed allowance at 0800 and $1800 \mathrm{~h}$ and the water was provided at $3 \mathrm{~L} / \mathrm{kg}$ feed supply. Pigs were fed the experimental diets for $10 \mathrm{~d}$ with the initial $5 \mathrm{~d}$ being an adjustment period. Five grams of ferric oxide, indigestible marker, was included to $100 \mathrm{~g}$ of feed in the morning meals of $d 6$ and 11. Fecal collection began with the first sign of marked feces after d 5 and stopped with the appearance of the marker in the feces after d 11. Fecal samples were collected from 0800 to $1800 \mathrm{~h}$ during the collection period. Urine collection started at $0800 \mathrm{~h}$ of $\mathrm{d} 6$ and ceased at 0800 h of d 11. A preservative of $50 \mathrm{~mL}$ of $6 \mathrm{~N}$ sulfuric acid was used for urine collection. Feces and urine were collected daily, weighed, and all the feces and a $20 \%$ subsample of the urine were stored at $-20^{\circ} \mathrm{C}$ until further analysis. All the collected samples were pooled per pig at the end of the experiment.

\section{Chemical analyses}

Feces and urine were oven-dried at $55^{\circ} \mathrm{C}$. Diets and feces were ground through a $0.75-\mathrm{mm}$ sieve. Dry matter content was determined by drying samples at $105^{\circ} \mathrm{C}$ for 24 $\mathrm{h}$ in a drying oven (Precision Scientific Co., Chicago, IL, USA; method 934.01; AOAC 2006). Concentration of $\mathrm{P}$ in diets, feces and urine samples were determined using a colorimetric assay after a wet-ash digestion with nitric and perchloric acids (method 935.13; AOAC, 2006). The acid molybdate and Fiske-Subbarow reducer solution were added to wet-ashed samples to measure the concentrations of $\mathrm{P}$ through the formation of a phosphomolybdenum complex by spectrophotometry at a wavelength of $620 \mathrm{~nm}$ (SpectraCount, model AS1000, Packard, Meriden, CT, USA; method 946.06; AOAC, 2006). Concentration of $\mathrm{Ca}$ in the supernatant of nitric and perchloric acids-digested diets was determined using flame atomic absorption spectrometry (AAnalyst 300, Perkin Elmer, Norwalk, CT, USA; method 985.01; AOAC, 2006). The $\mathrm{N}$ contents in diets, feces and urine were analyzed by the combustion method (method 990.03; AOAC, 2006).

\section{Calculations and statistical analysis}

Feed refusal was used to adjust total nutrient consumption. The apparent total tract digestibility (ATTD) of $\mathrm{P}$ and $\mathrm{N}$ were calculated by the following equation:

$$
\operatorname{ATTD}(\%)=100 \times\left(\mathrm{P}_{\mathrm{I}}-\mathrm{P}_{\mathrm{O}}\right) / \mathrm{P}_{\mathrm{I}},
$$

where $P_{I}$ represents the dietary $P(\mathrm{mg} / \mathrm{d})$ or $\mathrm{N}(\mathrm{g} / \mathrm{d})$ intake; and $\mathrm{P}_{\mathrm{O}}$ is the fecal $\mathrm{P}(\mathrm{mg} / \mathrm{d})$ or $\mathrm{N}(\mathrm{g} / \mathrm{d})$ output. Digested $\mathrm{P}$ or $\mathrm{N}\left(\mathrm{P}_{\mathrm{D}}\right)$ is calculated by the difference between dietary $\mathrm{P}$ or $\mathrm{N}$ intake and fecal $\mathrm{P}$ or $\mathrm{N}$ output. The TTTD of
$\mathrm{P}$ or $\mathrm{N}$ in $\mathrm{SBM}$ was determined by regressing $\mathrm{P}_{\mathrm{D}}$ against $\mathrm{P}_{\mathrm{I}}$ for diets with or without casein supplementation using the following model:

$$
\mathrm{P}_{\mathrm{D}}=\left(\mathrm{TTTD} \times \mathrm{P}_{\mathrm{I}}\right)-\mathrm{EPL},
$$

where TTTD (\%) is the slope of the regression; and EPL $(\mathrm{mg} / \mathrm{d})$ is the negative intercept of the regression.

The MIXED procedure was used for data analysis, and pig served as the experimental unit. Casein, dietary total $\mathrm{P}$ level, and the interaction of casein and P level were the fixed effects, and block was considered as the random effect in the model. Linear and quadratic contrasts were used examine the effects of $\mathrm{P}$ level within each diet type (with or without casein supplementation). Regression coefficients were compared between diets with or without casein supplementation. The differences in TTTD of $\mathrm{P}$ or $\mathrm{N}$ and EPL between pigs fed diets with or without casein supplementation were compared according to the pooled $t$ test (Zhai and Adeola, 2013). An $\alpha$ level of 0.05 was used to represent significance level.

\section{RESULTS}

All barrows were healthy and consumed all the provided feed, except one mortality at the beginning of the study in one of the casein-supplemented diets. The analyzed concentrations of $\mathrm{Ca}, \mathrm{P}$, and $\mathrm{N}$ in experimental diets were close to the calculated values (Table 1).

Daily balance and ATTD of P are presented in Table 2. Dietary $\mathrm{P}$ intake, fecal $\mathrm{P}$ output, digested $\mathrm{P}$, and retained $\mathrm{P}$ increased linearly with graded increasing inclusion of $\mathrm{P}$ from SBM regardless of casein supplementation $(p<0.01)$. With increasing dietary $\mathrm{P}$ intake, urinary $\mathrm{P}$ output increased linearly for pigs fed diets with casein supplementation $(p<0.05)$. However, there was no effect of $P$ levels on $P$ output in urine for diets without casein supplementation. Consumption of casein-supplemented diets decreased fecal P output, increased digested and retained P, and ATTD and retention of $\mathrm{P}$ compared with pigs fed diets without casein $(p<0.01)$. There were interactive effects of casein supplementation and dietary $\mathrm{P}$ level on the ATTD and retention of $P(p<0.05)$. The ATTD and retention of $P$ tended to decrease for diets with added casein as dietary $\mathrm{P}$ increased (linear, $\mathrm{p}<0.10$ ). However, retention of $\mathrm{P}$ tended to increase with increasing dietary $\mathrm{P}$ levels without casein supplementation (linear, $\mathrm{p}<0.10$ ). The ATTD of $\mathrm{P}$ ranged from $31.25 \%$ to $35.84 \%$ or $44.97 \%$ to $51.15 \%$ for pigs fed diets without or with added casein, respectively.

Daily balance and ATTD of $\mathrm{N}$ are presented in Table 3. Fecal $\mathrm{N}$ output and urinary $\mathrm{N}$ output increased linearly $(p<0.01)$ with graded levels of SBM in each type of diet. There were interactive effects of casein inclusion and 
Table 2. Daily balance and apparent total tract digestibility (ATTD) of $P$ in pigs fed experimental diets (as-fed basis)

\begin{tabular}{|c|c|c|c|c|c|c|c|c|c|c|c|c|c|c|}
\hline \multirow{3}{*}{ Item } & \multirow{2}{*}{\multicolumn{3}{|c|}{$\begin{array}{c}\text { Without casein, } \\
\text { dietary total P level } \\
(\mathrm{g} / \mathrm{kg})\end{array}$}} & \multirow{2}{*}{\multicolumn{3}{|c|}{$\begin{array}{c}\text { With casein, } \\
\text { dietary total P level } \\
(\mathrm{g} / \mathrm{kg})\end{array}$}} & \multirow{3}{*}{$\begin{array}{l}\text { Standard } \\
\text { deviation }\end{array}$} & \multirow{3}{*}{ Casein } & \multirow{3}{*}{ P level } & \multirow{3}{*}{ Interaction } & \multicolumn{4}{|c|}{ p-value } \\
\hline & & & & & & & & & & & \multicolumn{2}{|c|}{ Without casein } & \multicolumn{2}{|c|}{ With casein } \\
\hline & 1.42 & 2.07 & 2.72 & 1.42 & 2.07 & 2.72 & & & & & Linear & Quadratic & Linear & Quadratic \\
\hline No. of pigs & 8 & 8 & 8 & 7 & 8 & 8 & & & & & & & & \\
\hline Initial body weight (kg) & 25.5 & 25.5 & 25.5 & 25.4 & 25.5 & 25.4 & 0.33 & 0.812 & 0.754 & 0.895 & 0.936 & 0.777 & 0.518 & 0.420 \\
\hline P intake (mg/d) & 1,305 & 1,988 & 2,661 & 1,343 & 1,947 & 2,630 & 31.6 & 0.028 & $<0.001$ & 0.003 & $<0.001$ & 0.711 & $<0.001$ & 0.008 \\
\hline Fecal P output (mg/d) & 899 & 1,317 & 1,713 & 652 & 1,047 & 1,448 & 111.1 & $<0.001$ & $<0.001$ & 0.957 & $<0.001$ & 0.824 & $<0.001$ & 0.946 \\
\hline Urinary P output (mg/d) & 19 & 18 & 21 & 19 & 21 & 28 & 7.9 & 0.159 & 0.137 & 0.410 & 0.581 & 0.699 & 0.028 & 0.579 \\
\hline Digested P (mg/d) & 406 & 671 & 948 & 691 & 900 & 1,182 & 102.9 & $<0.001$ & $<0.001$ & 0.713 & $<0.001$ & 0.905 & $<0.001$ & 0.432 \\
\hline ATTD of P $(\%)$ & 31.25 & 33.92 & 35.84 & 51.15 & 46.33 & 44.97 & 4.75 & $<0.001$ & 0.812 & 0.012 & 0.124 & 0.860 & 0.081 & 0.414 \\
\hline Retained P (mg/d) & 387 & 653 & 927 & 672 & 879 & 1,154 & 102.7 & $<0.001$ & $<0.001$ & 0.666 & $<0.001$ & 0.926 & $<0.001$ & 0.452 \\
\hline $\mathrm{P}$ retention $(\%)$ & 29.81 & 32.99 & 35.07 & 49.81 & 45.23 & 43.91 & 4.72 & $<0.001$ & 0.961 & 0.008 & 0.082 & 0.789 & 0.091 & 0.439 \\
\hline
\end{tabular}

dietary P level on digested $\mathrm{N}$, ATTD of $\mathrm{N}$, retained $\mathrm{N}$, and $\mathrm{N}$ retention $(\mathrm{p}<0.05)$. Digested $\mathrm{N}$ increased (linear, $\mathrm{p}<0.01$; quadratic, $p<0.01$ ) with graded levels of SBM regardless of diet type. The ATTD of $\mathrm{N}$ increased linearly $(\mathrm{p}<0.01)$ for pigs fed diets without casein and increased quadratically $(\mathrm{p}<0.05)$ for pigs fed diets with casein. There were linear and quadratic decreases $(\mathrm{p}<0.01)$ in $\mathrm{N}$ retention for pigs fed casein-supplemented diets. With increasing SBM inclusion, pigs fed casein-supplemented diets had increases (linear, $\mathrm{p}<0.01$; quadratic, $\mathrm{p}<0.01$ ) in retained $\mathrm{N}$, and pigs fed diets without casein had a linear increase $(\mathrm{p}<0.01)$ in retained $\mathrm{N}$.

There was significant linear relationship between dietary $\mathrm{P}$ intake and digested $\mathrm{P}$ for pigs fed each type of diet in the current study. This allowed for the estimates of EPL and TTTD of P associated with SBM for growing pigs by the regression method. According to the linear regression equations shown in Table 4, the estimated values of TTTD of $\mathrm{P}$ in SBM were $37.34 \%$ or $38.57 \%$ for pigs fed diets without or with added casein, respectively. There was no significant difference in determined values of TTTD of $P$ in SBM between pigs fed diets without and with casein inclusion. Furthermore, the determined intercepts representing for EPL were 66 or $-161 \mathrm{mg} / \mathrm{d}$ in pigs fed diets without or with casein supplementation, respectively. Theses determined values of EPL were not different from zero, which might be caused by the relative large variance with the estimates.

The estimates of TTTD of N in SBM were $94.26 \%$ or $94.43 \%$ for pigs fed diets without or with added casein, respectively, with their corresponding determined daily fecal endogenous $\mathrm{N}$ loss being 666 or $242 \mathrm{mg} / \mathrm{d}$ (Table 5). Dietary casein supplementation had no effect on the

Table 3. Daily balance and apparent total tract digestibility (ATTD) of $\mathrm{N}$ in pigs fed experimental diets (as-fed basis)

\begin{tabular}{|c|c|c|c|c|c|c|c|c|c|c|c|c|c|c|}
\hline \multirow{3}{*}{ Item } & \multirow{2}{*}{\multicolumn{3}{|c|}{$\begin{array}{c}\text { Without casein, } \\
\text { dietary total P level } \\
(\mathrm{g} / \mathrm{kg})\end{array}$}} & \multirow{2}{*}{\multicolumn{3}{|c|}{$\begin{array}{c}\text { With casein, } \\
\text { dietary total P level } \\
(\mathrm{g} / \mathrm{kg})\end{array}$}} & \multirow{3}{*}{$\begin{array}{l}\text { Standard } \\
\text { deviation }\end{array}$} & \multirow{3}{*}{ Casein } & \multirow{3}{*}{ P level } & \multirow{3}{*}{ Interaction } & \multicolumn{4}{|c|}{ p-value } \\
\hline & & & & & & & & & & & \multicolumn{2}{|c|}{ Without casein } & \multicolumn{2}{|c|}{ With casein } \\
\hline & 1.42 & 2.07 & 2.72 & 1.42 & 2.07 & 2.72 & & & & & Linear & $\overline{\text { Quadratic }}$ & Linear & Quadratic \\
\hline No. of pigs & 8 & 8 & 8 & 7 & 8 & 8 & & & & & & & & \\
\hline $\mathrm{N}$ intake $(\mathrm{g} / \mathrm{d})$ & 16.49 & 23.75 & 31.94 & 18.65 & 28.26 & 35.88 & 0.407 & $<0.001$ & $<0.001$ & $<0.001$ & $<0.001$ & 0.013 & $<0.001$ & $<0.001$ \\
\hline Fecal N output (g/d) & 1.60 & 2.08 & 2.46 & 1.34 & 1.71 & 2.29 & 0.205 & $<0.001$ & $<0.001$ & 0.418 & $<0.001$ & 0.629 & $<0.001$ & 0.268 \\
\hline Urinary N output (g/d) & 4.81 & 7.43 & 11.20 & 4.47 & 6.81 & 12.55 & 1.534 & 0.492 & $<0.001$ & 0.162 & $<0.001$ & 0.395 & $<0.001$ & 0.017 \\
\hline Digested N (g/d) & 14.89 & 21.67 & 29.48 & 17.32 & 26.55 & 33.59 & 0.427 & $<0.001$ & $<0.001$ & $<0.001$ & $<0.001$ & 0.009 & $<0.001$ & $<0.001$ \\
\hline ATTD of N (\%) & 90.29 & 91.26 & 92.30 & 92.82 & 93.95 & 93.61 & 0.738 & $<0.001$ & $<0.001$ & 0.025 & $<0.001$ & 0.903 & 0.485 & 0.031 \\
\hline Retained N (g/d) & 10.08 & 14.24 & 18.28 & 12.85 & 19.73 & 21.03 & 1.541 & $<0.001$ & $<0.001$ & 0.025 & $<0.001$ & 0.924 & $<0.001$ & $<0.001$ \\
\hline $\mathrm{N}$ retention $(\%)$ & 61.26 & 59.93 & 57.26 & 68.82 & 69.86 & 58.58 & 5.024 & $<0.001$ & $<0.001$ & 0.043 & 0.142 & 0.766 & $<0.001$ & 0.009 \\
\hline
\end{tabular}

Table 4. Linear relationship between digestible P and dietary P intake (mg/d) of pigs fed diets supplemented without or with casein

\begin{tabular}{lccc}
\hline Item & Without casein & With casein & p-value $^{1}$ \\
\hline Regression equation & & \\
Standard error of the slope & $\mathrm{Y}=0.3734 \mathrm{X}-65.9579$ & $\mathrm{Y}=0.3857 \mathrm{X}+160.6458$ & \\
Standard error of the intercept & 0.0460 & 0.0440 \\
$\mathrm{r}^{2}$ & 94.9160 & 91.1898 \\
Estimate of endogenous P loss (mg/d) & 0.7495 & 0.7851 & 0.095 \\
Estimate of true total tract P digestibility (\%) & 66 & 38.57 & 0.849 \\
No. of pigs & 37.34 & 23 & \\
\hline
\end{tabular}

${ }^{1}$ The p-values are resulted from $t$-test.

${ }^{2}$ Digested P was regressed against dietary P intake for pigs fed diets supplemented without or with casein, the slope represents an estimate of the true total tract $\mathrm{P}$ digestibility (\%) and the intercept represents an estimate of endogenous $\mathrm{P}$ loss (mg/d). 
Table 5. Linear relationship between digestible $\mathrm{N}$ and dietary $\mathrm{N}$ intake $(\mathrm{mg} / \mathrm{d})$ of pigs fed diets supplemented without or with casein

\begin{tabular}{|c|c|c|c|}
\hline Item & Without casein & With casein & $\overline{p-\text {-value }^{1}}$ \\
\hline Regression equation $^{2}$ & $Y=0.9426 X-0.6658$ & $Y=0.9443 X-0.2424$ & \\
\hline Standard error of the slope & 0.0065 & 0.0060 & \\
\hline Standard error of the intercept & 0.1625 & 0.1740 & \\
\hline$r^{2}$ & 0.9989 & 0.9991 & \\
\hline Estimate of endogenous $\mathrm{N}$ loss (mg/d) & 666 & 242 & 0.083 \\
\hline Estimate of true total tract $\mathrm{N}$ digestibility (\%) & 94.26 & 94.43 & 0.852 \\
\hline No. of pigs & 24 & 23 & \\
\hline
\end{tabular}

${ }^{1}$ The p-values are resulted from $t$-test.

${ }^{2}$ Digested $\mathrm{N}$ was regressed against dietary $\mathrm{N}$ intake for pigs fed diets supplemented without or with casein, the slope represents an estimate of true total tract digestibility of $\mathrm{N}(\%)$ and the intercept represents an estimate of endogenous $\mathrm{N}$ loss $(\mathrm{mg} / \mathrm{d})$.

estimates of TTTD of $\mathrm{N}$ in SBM and daily endogenous $\mathrm{N}$ loss for growing pigs.

\section{DISCUSSION}

To improve $\mathrm{P}$ utilization by pigs, it is important to estimate the digestibility of $\mathrm{P}$ in feedstuff for accurate diet formulation. Compared with apparent digestibility, the true digestibility of $\mathrm{P}$ preferred because of the correction for the endogenous loss (Fan et al., 2001; Petersen and Stein, 2006). The P-free diet, ${ }^{32} \mathrm{P}$-labeled phosphates and the regression method have been used to measure the tandrue digestibility of $\mathrm{P}$ in assay ingredients and EPL for animals (Al-Masri and Günther, 1988; Al-Masri, 1995; Fan et al., 2001; Dilger and Adeola, 2006; Petersen and Stein, 2006; Akinmusire and Adeola, 2009). Because of disturbances in normal physiologic status of animals from the P-free diets and the rapid recycling of ${ }^{32} \mathrm{P}$-labeled phosphates in the gut (AlMasri and Günther, 1988; Al-Masri, 1995; Petersen and Stein, 2006), the regression method is widely used to estimate the TTTD of P in test ingredients and EPL for pigs. However, there were little information about dietary factors affecting the use of the regression mathematical model and limitations of this approach have been published previously. To our knowledge, the concentrations of $\mathrm{P}$ in experimental diets are lower than the requirements of pigs and dietary $\mathrm{P}$ levels being within the linear response range are the only reported conditions influencing the use of regression analysis (Poulsen et al., 1999; Fan et al., 2001; Dilger and Adeola, 2006). This is because of the digestibility of $P$ in diets is depressed by excessive dietary phytate-P intake (Selle et al., 2009).

Dietary supplementation of casein, which is high in protein quality and digestibility of $\mathrm{P}$, did not affect regression-derived estimates of TTTD of $\mathrm{P}$ in SBM for pigs in the current study. However, added casein resulted in the determined value of EPL being negative even though the estimate was not different from zero. The estimation of EPL was considered as a key issue to measure TTTD of P because the values of EPL are needed for correcting ATTD of P. However, the novel finding of the current study suggests that the estimates of TTTD of P in assay ingredients are not dependent on the accurate determination of EPL by regressing daily digested $\mathrm{P}$ against daily $\mathrm{P}$ intake. In agreement with previous publications using SBM as the test feedstuff, a strong linear relationship between digested $\mathrm{P}$ and dietary total $\mathrm{P}$ intake was observed in this study, which meet the requirement for the use of the regression method (Fan et al., 2001; Dilger and Adeola, 2006; Akinmusire and Adeola, 2009). As expected, diets supplemented with casein increased the ATTD of P due to the higher digestibility of $\mathrm{P}$ in casein than that in SBM (NRC, 2012). This is reflected in the ATTD of $P$ ranging from $31.25 \%$ to $35.84 \%$ in diets without casein and $44.97 \%$ to $51.15 \%$ in diets with casein supplementation. The estimates of TTTD of P in SBM are $37.3 \%$ and $38.6 \%$ in diets without and with casein supplementation, respectively, in the current study. Our determined values of TTTD of P were lower than the estimates of $48.5 \%$ and $44.5 \%$ for SBM reported by Fan et al. (2001) and Dilger and Adeola (2006), whereas consistent with the estimates of $40.9 \%$ and $36.0 \%$ reported by Akinmusire and Adeola (2009) and Zhai and Adeola (2013). The current regression-derived estimates of TTTD of P in SBM are in agreement with Liu et al. (2014b), who reported that the determined values of TTTD of $P$ in SBM are $41.0 \%$ and $37.5 \%$ for pigs fed a cornstarch-based semi-purified diet and a corn-based practical diet, respectively. The differences in the TTTD of $\mathrm{P}$ in SBM among previous studies and the current experiment may be due to dietary Ca:total $\mathrm{P}$ ratio, which was shown in broiler by Liu et al. (2013). There was no dietary limestone inclusion in the study of Fan et al. (2001) and Dilger and Adeola (2006), whereas dietary Ca:total $\mathrm{P}$ ratio was maintained at 1.2 by limestone supplementation in the current work and the study of Liu et al. (2014b). Furthermore, $\mathrm{P}$ digestibility in the basal diets does not affect the determination of TTTD of P in SBM in the current study, which is consistent with the study of Liu et al. (2014b). However, effects of $\mathrm{P}$ digestibility and levels in basal diets on the determination of true ileal digestibility of P in SBM 
for broiler chickens were not consistent between the studies of Liu et al. (2014a) and Mutucumarana et al. (2015). There was no effect of casein supplementation $(50.0 \mathrm{~g} / \mathrm{kg})$ on the estimates of true ileal digestibility of P in SBM for chickens fed diets at total P from 1.02 to $2.55 \mathrm{~g} / \mathrm{kg}$ (Liu et al., 2014a), whereas dietary dried egg albumen addition decreased the determined values of true ileal $\mathrm{P}$ digestibility in SBM for chickens fed diets at total $P$ from 2.77 to $4.82 \mathrm{~g} / \mathrm{kg}$ (Mutucumarana et al., 2015). The differences in the range of total $\mathrm{P}$ levels of experimental diets are probably responsible, in part, for the differences between the study of Liu et al. (2014a) and Mutucumarana et al. (2015).

In the current study, dietary casein inclusion did not affect the estimate of EPL associated with SBM in pigs using the regression technique. This indicates that the negative intercepts derived from regressing digested $P$ against dietary total $\mathrm{P}$ intake cannot be used for EPL estimation while additional ingredients containing high digestible $\mathrm{P}$ are included in the basal diets. This notion has been reported previously (Liu et al., 2014a). The slope and the negative intercepts represent the TTTD of P and EPL by the regression method, respectively. The following equations may responsible for dietary casein supplementation affects the negative intercepts while the estimates of TTTD of P in SBM was not altered:

$$
\begin{aligned}
& \mathrm{P}_{\mathrm{D}}=\mathrm{TTTD}_{\mathrm{SBM}} \times \mathrm{P}_{\mathrm{SBM}}+\mathrm{TTTD}_{\text {casein }} \times \mathrm{P}_{\text {casein }}-\mathrm{EPL} \\
& \mathrm{P}_{\mathrm{D}}=\mathrm{TTTD}_{\mathrm{SBM}} \times\left(\mathrm{P}_{\mathrm{I}}-\mathrm{P}_{\text {casein }}\right)+\mathrm{TTTD}_{\text {casein }} \times \mathrm{P}_{\text {casein }}-\mathrm{EPL} \\
& \mathrm{P}_{\mathrm{D}}=\mathrm{TTTD}_{\mathrm{SBM}} \times \mathrm{P}_{\mathrm{I}}+\mathrm{P}_{\text {casein }} \times\left(\mathrm{TTTD}_{\text {casein }}-\mathrm{TTTD}_{\mathrm{SBM}}\right)-\mathrm{EPL}
\end{aligned}
$$

where TTTD $_{\text {SBM }}$ and TTTD $_{\text {casein }}$ represent the TTTD of P (\%) in $\mathrm{SBM}$ and casein, respectively; $\mathrm{P}_{\mathrm{SBM}}$ and $\mathrm{P}_{\text {casein }}$ is dietary $\mathrm{P}(\mathrm{mg} / \mathrm{d})$ originate from $\mathrm{SBM}$ and casein, respectively; $\mathrm{P}_{\mathrm{D}}$ is digested $\mathrm{P}(\mathrm{mg} / \mathrm{d}) ; \mathrm{P}_{\mathrm{I}}$ is dietary total $\mathrm{P}$ intake $(\mathrm{mg} / \mathrm{d})$, and EPL is EPL $(\mathrm{mg} / \mathrm{d})$. These equations indicate that the negative intercept is $\mathrm{EPL}+\mathrm{P}_{\text {casein }} \times$ $\left(\right.$ TTTD $\left._{\mathrm{SBM}}-\mathrm{TTTD}_{\text {casein }}\right)$ using a linear regression of $\mathrm{P}_{\mathrm{D}}$ on $\mathrm{P}_{\mathrm{I}}$. However, the TTTD $\mathrm{SBM}_{\mathrm{S}}$ is lower than TTTD $_{\text {casein. }}$ Therefore, the determined negative intercept representing for EPL is negative when adequate amounts of $\mathrm{P}$ derived from casein was supplemented in the basal diet. These equations suggested by Liu et al. (2014b), indicated that the $\mathrm{P}_{\mathrm{D}}$ is increased by graded $\mathrm{P}_{\mathrm{I}}$ derived from SBM because the increased dietary $\mathrm{P}$ intake is due to increasing inclusion of SBM. Therefore, it is reasonable that the estimates of slope representing for TTTD of $\mathrm{P}$ in SBM were not affected by constant casein addition in the basal diet. In the current study, the estimate of EPL associated with SBM in pigs is $66 \mathrm{mg} / \mathrm{d}$, which is consistent with the $48 \mathrm{mg} / \mathrm{d}$ reported by Akinmusire and Adeola (2009). The values of EPL reported in previous studies ranged from $70 \mathrm{mg} / \mathrm{kg}$ of dry matter intake (DMI) (Dilger and Adeola, 2006; Pettey et al., 2006) to $670 \mathrm{mg} / \mathrm{kg}$ of DMI (Shen et al., 2002) by regression method. Using the P-free diet, an estimate of EPL at 139 $\mathrm{mg} / \mathrm{kg}$ of DMI was also reported by Petersen and Stein (2006). Jongbloed et al. (1991) indicated that EPL is decreased when $\mathrm{P}$ intake is lower than the requirements for $\mathrm{P}$. However, dietary concentration of $\mathrm{P}$ being lower than the requirements of the animal is a fundamental condition needed for using regression approach (Poulsen et al., 1999; Fan et al., 2001; Dilger and Adeola, 2006). Taken together, accurate EPL is not an essential requirement for reliable estimate of regression-derived TTTD of $\mathrm{P}$ in test feedstuffs.

In the current study, the ATTD of $\mathrm{N}$ increased with increasing levels of SBM. This may be due to decreased ratio of endogenous $\mathrm{N}$ loss to fecal $\mathrm{N}$ output derived from indigested $\mathrm{N}$ from SBM as dietary SBM level increased. As expected, pigs fed casein-supplemented diets had lower fecal $\mathrm{N}$ output than pigs fed diets without casein, thus leading to greater ATTD and retention of N. Consistent with the effects of casein supplementation on the estimate of TTTD of $\mathrm{P}$, the determined values of TTTD of $\mathrm{N}$ in SBM were not influenced by dietary casein inclusion.

In conclusion, the regression-derived estimates of TTTD of P in SBM were not influenced by supplementing casein at $50 \mathrm{~g} / \mathrm{kg}$ basal diet. The negative EPL for pigs fed diets with casein supplementation resulted from greater $\mathrm{P}$ digestibility in casein than that in SBM. Therefore, feedstuffs containing highly digestible protein and $\mathrm{P}$ can be included in cornstarch-based diets to determine the TTTD of $\mathrm{P}$ in the assay ingredients using the regression method.

\section{CONFLICT OF INTEREST}

We certify that there is no conflict of interest with any financial organization regarding the material discussed in the manuscript.

\section{ACKNOWLEDGMENTS}

The authors gratefully acknowledge Pat Jaynes, Hengxiao Zhai, and Pengcheng Xue (Purdue University, West Lafayette, IN, USA) for their varied roles in the conduct of and contribution to this study.

\section{REFERENCES}

Adeola, O. and K. E. Ileleji. 2009. Comparison of two diet types in the determination of metabolizable energy content of corn distillers dried grains with solubles for broiler chickens by the regression method. Poult. Sci. 88:579-585.

Al-Masri, M. R. 1995. Absorption and endogenous excretion of phosphorus in growing broiler chicks, as influenced by calcium and phosphorus ratios in feed. Br. J. Nutr.74:407-415.

Ajakaiye, A., M. Z. Fan, T. Archbold, R. R. Hacker, C. W. 
Forsberg, and J. P. Phillips. 2003. Determination of true digestive utilization of phosphorus and the endogenous phosphorus outputs associated with soybean meal for growing pigs. J. Anim. Sci. 81:2766-2775.

Akinmusire, A. S. and O. Adeola. 2009. True digestibility of phosphorus in canola and soybean meals: Influence of microbial phytase. J. Anim. Sci. 87:977-983.

AOAC (Association of Official Analytical Chemists International). 2006. Official Methods of Analysis. 18th edn. Association of Official Analytical Chemists, Arlington, VA, USA.

Cromwell, G. L. 1980. Biological availability of phosphorus for pigs. Feedstuffs 52:38-42.

Dilger, R. N. and O. Adeola. 2006. Estimation of true phosphorus digestibility and endogenous phosphorus loss in growing pigs fed conventional and low-phytate soybean meals. J. Anim. Sci. 84:627-634.

Fan, M. Z., T. Archbold, W. C. Sauer, D. Lackeyram, T. Rideout, Y. Gao, C. F. M. de Lange, and R. R. Hacker. 2001. Novel methodology allows simultaneous measurement of true phosphorus digestibility and the gastrointestinal endogenous phosphorus outputs in studies with pigs. J. Nutr. 131:23882396.

Fan, M. Z. and W. C. Sauer. 2002. Additivity of apparent ileal and fecal phosphorus digestibility values measured in single feed ingredients for growing-finishing pigs. Can. J. Anim. Sci. 82:183-191.

Al-Masri, M. R. and K. D. Günther. 1988. The influence of different phosphorus supply on phosphorus turnover in growing broiler chicks by means of ${ }^{32} \mathrm{P}$ isotope. Aalam AlZarra. 7-14.

Jongbloed, A. W., H. Everts, and P. A. Kemme. 1991. Phosphorous availability and requirements in pigs. In: Recent Advances in Animal Nutrition. (Eds. W. Haresign and D. J. A. Cole). Butterworth, London, UK. pp. 65-80.

Jongbloed, A. W., Z. Mroz, and P. A. Kemme. 1992. The effect of supplementary Aspergillus niger phytase in diets for pigs on concentration and apparent digestibility of dry matter, total phosphorus, and phytic acid in different sections of the alimentary tract. J. Anim. Sci. 70:1159-1168.

Liu, J. B., D. W. Chen, and O. Adeola. 2013. Phosphorus digestibility response of broiler chickens to dietary calcium-tophosphorus ratios. Poult. Sci. 92:1572-1578.

Liu, J. B., D. W. Chen, and O. Adeola. 2014a. Casein supplementation does not affect true phosphorus digestibility and endogenous phosphorus loss associated with soybean meal for broiler chickens determined by the regression method. Can. J. Anim. Sci. 94:661-668.
Liu, J. B., Y. K. Yang, J. He, and F. K. Zeng. 2014b. Comparison of two diet types in the estimation of true digestibility of phosphorus in soybean and canola meals for growing pigs by the regression method. Livest. Sci. 167: 269-275.

Mutucumarana, R. K., V. Ravindran, G. Ravindran, and A. J. Cowieson. 2015. Measurement of true ileal phosphorus digestibility in maize and soybean meal for broiler chickens: Comparison of two methodologies. Anim. Feed Sci. Technol. 206:76-86.

NRC (National Research Council). 2012. Nutrient Requirements of Swine. 11th edn. National Academy Press, Washington, DC, USA.

Petersen, G. I. and H. H. Stein. 2006. Novel procedure for estimating endogenous losses and measurement of apparent and true digestibility of phosphorus by growing pigs. J. Anim. Sci. 84:2126-2132.

Pettey, L. A., G. L. Cromwell, and M. D. Lindemann. 2006. Estimation of endogenous phosphorus loss in growing and finishing pigs fed semipurified diets. J. Anim. Sci. 84:618-626.

Poulsen, H. D., A. W. Jongbloed, P. Latimier, and J. A. Fernández. 1999. Phosphorus, consumption, utilization and losses in pig production in France, The Netherlands and Denmark. Livest. Prod. Sci. 58:251-259.

Raboy, V. 1997. Accumulation and Storage of Phosphate and Minerals. In: Cellular and Molecular Biology of Plant Seed Development (Eds. B. A. Larkins and I. K. Vasil). Springer Netherlands, Dordrecht, The Netherlands. pp. 441-477.

Selle, P. H., A. J. Cowieson, and V. Ravindran. 2009. Consequences of calcium interactions with phytate and phytase for poultry and pigs. Livest. Sci. 124:126-141.

Shen, Y., M. Z. Fan, A. Ajakaiye, and T. Archbold. 2002. Use of the regression analysis technique to determine the true phosphorus digestibility and the endogenous phosphorus output associated with corn in growing pigs. J. Nutr. 132:11991206.

Stein, H. H., C. T. Kadzere, S. W. Kim, and P. S. Miller. 2008. Influence of dietary phosphorus concentration on the digestibility of phosphorus in monocalcium phosphate by growing pigs. J. Anim. Sci. 86:1861-1867.

Weremko, D., H. Fandrejewski, T. Zebrowska, I. K. Han, J. H. Kim, and W. T. Cho. 1997. Bioavailability of phosphorus in feeds of plant origin for pigs. Asian Australas J. Anim. Sci. 10:551-566.

Zhai, H. and O. Adeola. 2013. True total-tract digestibility of phosphorus in corn and soybean meal for fifteen-kilogram pigs are additive in corn-soybean meal diet. J. Anim. Sci. 91:219224. 